\title{
Platelet hyperactivity in sickle-cell disease: a consequence of hyposplenism
}

\author{
MW KENNY, AJ GEORGE, AND J STUART \\ From the Department of Haematology, University of Birmingham and the Department of Haematology, \\ Queen Elizabeth Hospital, Birmingham B15 2TH, UK
}

SUMMARY Platelet function was measured on 29 occasions in 16 adult patients in the asymptomatic steady state of sickle-cell anaemia. There was a significant increase in platelet number and microaggregate formation, and a lower aggregation threshold with adenosine diphosphate, compared with 23 healthy controls. Similar changes were found, however, in 12 splenectomised patients without sickle-cell disease. The platelet hyperactivity of the sickle-cell steady state therefore reflects an increased circulating population of young, metabolically active platelets resulting from previous autosplenectomy.

\begin{abstract}
Although the irreversibly sickled cell is the major cause of vascular obstruction in the painful vasoocclusive crisis of sickle-cell disease, there is evidence that platelets are also involved. Liver biopsy during sickle-cell crisis has revealed platelet masses in association with aggregates of sickled cells, ${ }^{1}$ the platelet count may fall during crisis compared with steady-state values, ${ }^{23}$ and there is a reduction in platelet survival. ${ }^{4}$ Clinical recovery is associated with a rebound thrombocytosis. ${ }^{35}$

It is important to determine whether these changes are secondary to vascular stasis and endothelial damage during crisis ${ }^{6}$ or whether there is pre-existing platelet activation during the steady state which contributes to the onset of vaso-occlusive crisis. Published reports of platelet function in asymptomatic sickle-cell disease have given conflicting results: platelet aggregability has been reported as increased, ${ }^{7}$ normal, 48 and decreased, 9 with either no change 4 or decreased aggregability 89 during crisis. There is, however, one report of aspirindipyridamole prophylaxis causing a small reduction in symptomatic episodes in three patients. ${ }^{10}$

The present study was designed to examine platelet function during the steady state in comparison with healthy controls and splenectomised patients.
\end{abstract}

\section{Patients and methods}

Blood samples were obtained, without venostasis,

Received for publication 15 October 1979 from 16 patients with sickle-cell disease $(12 \mathrm{~S} / \mathrm{S}$, three $\mathrm{S} / \beta$ thalassaemia, and one $\mathrm{S} / \mathrm{C}$ disease) of mean age 20.7 (range 15-42) years at routine outpatient visits. Each patient was studied on an average of two occasions in the steady state and had been asymptomatic for at least four weeks before testing; it has been shown that the haemostatic abnormalities, including rebound thrombocytosis, of sickle-cell crisis return to normal within four weeks. ${ }^{5}$ None of the patients had palpable splenomegaly. Blood was obtained under identical conditions from a control group of 23 healthy subjects of mean age $24 \cdot 7$ (range 19-30) years. The tests which showed a statistically significant difference between these two groups (see Table) were subsequently performed on blood from 12 splenectomised patients without sickle-cell disease of mean age 19.9 (range 7-33) years. The splenectomy had previously been performed, as part of the staging procedure for lymphoma, at least three months previously, and the patients were not currently receiving cytotoxic drugs or radiotherapy. All the patients had also avoided, for at least two weeks, any drugs that interfere with platelet function.

Platelet counts, using EDTA-anticoagulated blood, were performed using the ThrombofugeThrombocounter system (Coulter Electronics Ltd). Blood for platelet function studies was collected into $1 / 10$ th volume of $3.13 \%$ trisodium citrate in polystyrene tubes and centrifuged once at $22^{\circ} \mathrm{C}$ and $200 \mathrm{~g}$ for 10 minutes, to produce platelet rich plasma (PRP), and then for $15-20$ minutes at $22^{\circ} \mathrm{C}$ and $1500 \mathrm{~g}$, to obtain platelet-poor plasma (PPP). The platelet counts of PRP were adjusted to $300 \times 10^{9} / 1$ 
Table Mean $( \pm S D)$ results for the sickle-cell steady state compared with healthy controls and postsplenectomy patients

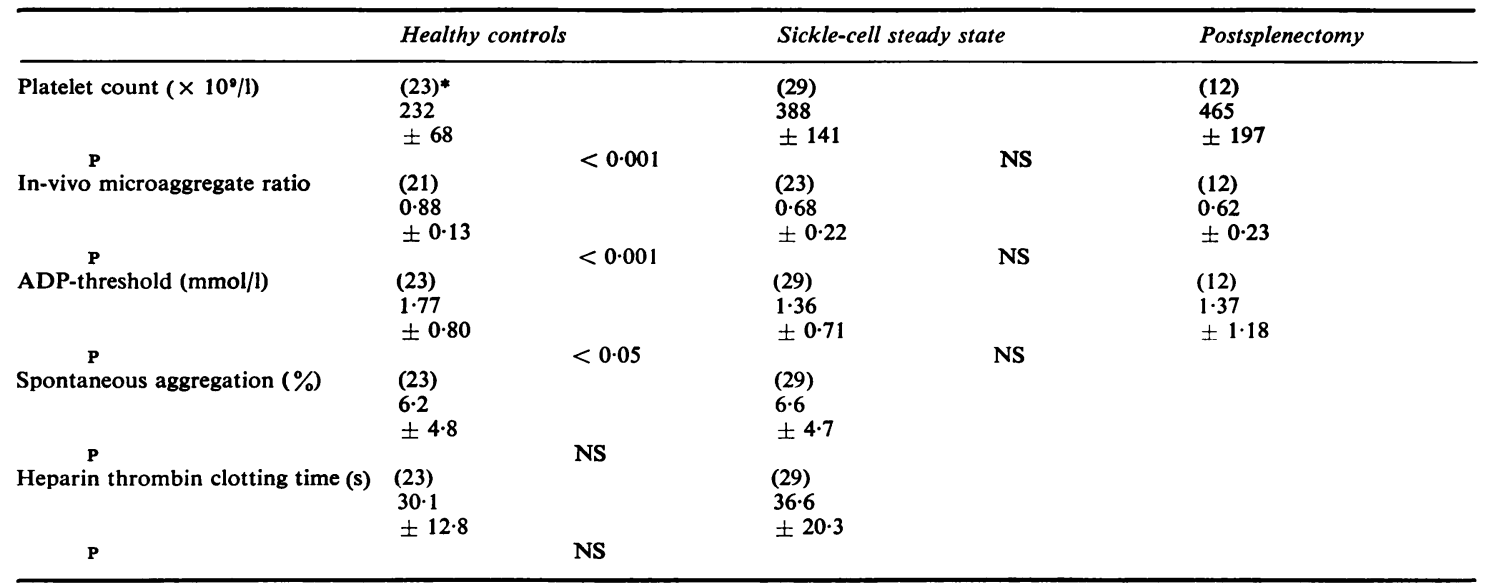

*Number of tests in parentheses.

using autologous PPP, kept in capped polystyrene tubes at room temperature, and tested within 45 minutes.

Spontaneous platelet aggregation was performed by a modification of the method of Wu and Hoak ${ }^{11}$ using $0.5 \mathrm{ml}$ PRP mixed for 10 minutes at $700 \mathrm{rpm}$ and at $37^{\circ} \mathrm{C}$ in a dual-channel platelet aggregometer (Malin Electronics Ltd, Ayr, Scotland) attached to a Vitatron 2001 recorder (MSE-Fisons Ltd, Crawley, Sussex). Transmission was adjusted to $0 \%$ for PRP and to $100 \%$ for PPP. The change in transmission was recorded as percentage spontaneous aggregation.

The minimum adenosine diphosphate (ADP) concentration required to produce a biphasic aggregation response (ADP threshold) was determined by adding $0.1 \mathrm{ml}$ ADP (BDH Chemicals Ltd, Poole, Dorset) to $0.5 \mathrm{ml}$ PRP to give final concentrations ranging from 0.2 to $5.5 \mathrm{mmol} / 1 \mathrm{PRP}$.

Platelet in vivo microaggregate ratios were measured by the formalin-fixation method of $\mathrm{Wu}$ and Hoak ${ }^{12}$ but using twice the volume of blood and buffer to improve accuracy.

The heparin thrombin clotting time (platelet factor 4-like activity) was determined according to O'Brien et al. ${ }^{13}$ using a thrombin concentration of 6 units $/ \mathrm{ml}$ and adjusting the heparin concentration to give a control time of 25 seconds for pooled normal plasma.

Statistical significance was determined by the Mann-Whitney U test.

\section{Results}

Patients with sickle-cell disease, compared with healthy controls, showed a significantly higher platelet count, lower in vivo microaggregate ratio, and lower ADP threshold (see Table). There was no significant difference in spontaneous aggregation or heparin thrombin clotting time.

When the results for sickle-cell patients were compared with those for postsplenectomy patients, there was no significant difference in platelet count, in vivo microaggregate ratio, or ADP threshold.

\section{Discussion}

This study of asymptomatic sickle-cell anaemia has shown a significant increase in platelet number and microaggregate formation and a lower threshold for ADP-induced aggregation, compared with healthy controls of similar age. The raised platelet count has previously been reported ${ }^{14-17}$ and an increase in large platelets (megathrombocytes) was also demonstrated in one study. ${ }^{16}$ It is particularly important to select appropriate control patients in studies of sickle-cell disease, ${ }^{18}$ and when we included a second control group of adult asplenic patients we could no longer demonstrate these differences in platelet number and function.

Functional asplenia, as determined by reduced uptake of isotope, develops in childhood sickle-cell disease $^{19}$ and is followed by ischaemia-induced fibrotic atrophy. ${ }^{20}$ Splenectomised adults, without sickle-cell disease, have a thrombocytosis ${ }^{21} 22$ caused by loss of the normal splenic platelet pool which contains up to one-third of the total body platelet mass. ${ }^{23}$ Absence of this pool has also been demonstrated in sickle-cell anaemia. ${ }^{24}$ The spleen has been 
shown to retain newly formed platelets for up to two days before their release into the circulation ${ }^{25}$ and to contain many large platelets ${ }^{26}$ which are young, ${ }^{27}$ more active metabolically, ${ }^{28} 29$ and show greater responsiveness in platelet function tests. 3031 The few studies of platelet function after splenectomy have shown normal adhesiveness ${ }^{32} 33$ but increased aggregation with ADP and also collagen. ${ }^{33}$

Thus the apparent platelet hyperactivity of the sickle steady state reflects the absence of splenic pooling of young active platelets rather than chronic intravascular activation of platelets in the microcirculation. Although a recent study of 318 postsplenectomy patients showed no significant association between postsplenectomy thrombocytosis and thromboembolism, ${ }^{34}$ the increased number of circulating active platelets in sickle-cell disease may readily lead to aggregation in areas of stasis during vaso-occlusive crisis. This is consistent with the fall in platelet count, ${ }^{23}$ reduction in platelet survival, ${ }^{4}$ and decrease in aggregability of the remaining circulating platelets. 89

Platelet hyperactivity in the steady state, and also platelet activation during crisis, now appear to be secondary phenomena, and it seems unlikely that antiplatelet therapy could have a major effect in reducing the frequency or severity of sickle-cell crises.

We are indebted to Mr K Matthews, Department of Hospital Statistics, Queen Elizabeth Medical Centre, for help with the statistical analysis and to Dr KE Barrett and Dr JR Mann for referring patients.

\section{References}

${ }^{1}$ Rosenblate HJ, Eisenstein R, Holmes AW. The liver in sickle cell anemia: a clinical-pathologic study. Arch Pathol 1970;90:235-45.

${ }^{2}$ Gordon PA, Breeze GR, Mann JR, Stuart J. Coagulation fibrinolysis in sickle-cell disease. J Clin Pathol 1974;27:485-9.

${ }^{3}$ Ittyerah R, Alkjaersig N, Fletcher A, Chaplin $\mathbf{H}$. Coagulation factor XIII concentration in sickle-cell disease. J Lab Clin Med 1976;88:546-54.

${ }^{4}$ Haut MJ, Cowan DH, Harris JW. Platelet function and survival in sickle cell disease. $J$ Lab Clin Med $1973 ; 82: 44-53$.

${ }^{5}$ Alkjaersig N, Fletcher A, Joist H, Chaplin H, Jr. Hemostatic alterations accompanying sickle cell pain crises. J Lab Clin Med 1976;88:440-9.

${ }^{6}$ Rickles FR, O'Leary DS. Role of coagulation system in pathophysiology of sickle cell disease. Arch Intern Med 1974;133:635-41.

' Barnhart MI, Vettraino A, Lusher JM. Microscopy as an aid in the evaluation and management of sickle cell anemia. Thromb Diath Haemorrh 1973;Suppl 53: 193-214.
${ }^{8}$ Stuart MJ, Stockman JA, Oski FA. Abnormalities of platelet aggregation in the vaso-occlusive crisis of sickle-cell anemia. J Pediatr 1974;85:629-32.

${ }^{9}$ Gruppo RA, Glueck HI, Granger SM, Miller MA. Platelet function in sickle cell anemia. Thromb Res 1977;10:325-35.

${ }^{10}$ Alkjaersig N, Chaplin H, Fletcher AP. Experience with aspirin-dipyridamole prophylaxis in sickle cell disease. Thromb Haemost 1979;42:60. (Abstract)

${ }^{11} \mathrm{Wu}$ KK, Hoak JC. Spontaneous platelet aggregation in arterial insufficiency: mechanisms and implications. Thromb Haemost 1976;35:702-11.

$12 \mathrm{Wu}$ KK, Hoak JC. A new method for the quantitative detection of platelet aggregates in patients with arterial insufficiency. Lancet 1974;2:924-6.

${ }^{13}$ O'Brien JR, Etherington M, Jamieson S, Lawford P. Heparin thrombin clotting-time and platelet factor 4. Lancet 1974;2:656-7. (Letter)

${ }^{14}$ Green D, Kwaan HC, Ruiz G. Impaired fibrinolysis in sickle cell disease. Relation to crisis and infection. Thromb Diath Haemorrh 1970;24:10-6.

${ }^{15}$ Walsh RT, Lusher JM, Barnhart MI. Coagulation and fibrinolysis studies in sickle cell anemia. Thromb Diath Haemorrh 1973;Suppl 53:271-9.

${ }^{16}$ Freedman ML, Karpatkin S. Short communication: elevated platelet count and megathrombocyte number in sickle cell anemia. Blood 1975;46:579-82.

${ }^{17}$ Leslie J, Langler D, Serjeant GR, Serjeant BE, Desai P, Gordon YB. Coagulation changes during the steady state in homozygous sickle-cell disease in Jamaica. Bri J Haematol 1975;30:159-66.

${ }^{18}$ Richardson SGN, Matthews KB, Stuart J, Geddes AM, Wilcox RM. Serial changes in coagulation and viscosity during sickle-cell crisis. Brit J Haematol $1979 ; 41: 95-103$.

19 Pearson HA, Spencer RP, Cornelius EA. Functional asplenia in sickle cell anemia. $N$ Engl $J$ Med 1969; 281:923-6.

${ }^{20}$ Diggs LW. Siderofibrosis of the spleen in sickle cell anemia. JAMA 1935;104:538-41.

${ }^{21}$ Singer K, Miller EB, Dameshek W. Hematologic changes following splenectomy in man, with particular reference to target cells, hemolytic index and lysolecithin. Am J Med Sci 1941;202:171-87.

${ }^{22}$ Lipson RL, Bayrd ED, Watkins CH. The postsplenectomy blood picture. Am J Clin Pathol 1959;32:526-32.

${ }^{23}$ Aster RH. Pooling of platelets in the spleen: Role in the pathogenesis of 'hypersplenic' thrombocytopenia. J Clin Invest 1966;45:645-57.

${ }^{24}$ Schwartz AD. The splenic platelet reservoir in sickle cell anemia. Blood 1972;40:678-83.

${ }^{25}$ Shulman NR, Watkins SP, Jr, Itscoitz SB, Students AB. Evidence that the spleen retains the youngest and hemostatically most effective platelets. Trans Assoc Am Physicians 1968;81:302-13.

${ }^{26}$ Freedman ML, Karpatkin S. Heterogeneity of rabbit platelets. V. Preferential splenic sequestration of megathrombocytes. Brit J Haematol 1975;31 :255-62.

${ }^{27}$ Amorosi E, Garg SK, Karpatkin S. Heterogeneity of human platelets. IV. Identification of a young platelet population with $\left({ }^{75} \mathrm{Se}\right)$ selenomethionine. Brit $J$ Haematol 1971 ;21:227-32. 
${ }^{28}$ Karpatkin S, Charmatz A. Heterogeneity of human platelets. I. Metabolic and kinetic evidence suggestive of young and old platelets. J Clin Invest 1969;48: 1073-82.

${ }^{29}$ Karpatkin S, Charmatz A. Heterogeneity of human platelets. III. Glycogen metabolism in platelets of different sizes. Brit J Haematol 1970;19:135-43.

${ }^{30}$ Mannucci PM, Sharp AA. Platelet volume and shape in relation to aggregation and adhesion. Brit $J$ Haematol 1967;13:604-17.

${ }^{31}$ Karpatkin S. Heterogeneity of human platelets. II. Functional evidence suggestive of young and old platelets. J Clin Invest 1969;48:1083-7.

${ }^{32}$ McClure PD, Ingram GIC, Stacey RS, Glass UH,
Matchett MO. Platelet function tests in thrombocythaemia and thrombocytosis. Brit $J$ Haematol 1966;12:478-98.

${ }^{33}$ Zucker S, Mielke CH. Classification of thrombocytosis based on platelet function tests: Correlation with hemorrhagic and thrombotic complications. $J$ Lab Clin Med 1972;80:385-94.

${ }^{34}$ Boxer MA, Braun J, Ellman L. Thromboembolic risk of postsplenectomy thrombocytosis. Arch Surg 1978; 113:808-9.

Requests for reprints to: Professor J Stuart, Queen Elizabeth Hospital, Birmingham B15 2TH, UK.

\section{Reports and Bulletins prepared by the Association of Clinical Biochemists}

The following reports and bulletins are published by the Association of Clinical Biochemists. They may be obtained from The Publishing Department, British Medical Journal (ACB Technical Bulletins), BMA House, Tavistock Square, London WC1H 9JR. Overseas readers should remit by British Postal or Money Order.

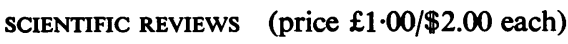

1 The assessment of thyroid function March 1971 FV FLYNN and JR HOBBS

2 Renal function tests suitable for clinical practice January 1972 FL MITCHELL, N VEALL, and RWE WATTS

3 Biochemical tests for the assessment of fetoplacental function May 1975 CE WILDE and RE OAKEY

4 Test of exocrine pancreatic function March 1977 AH GOWENLOCK

5 Assay of cholinesterase in clinical chemistry 1979 ELSIE SILK, J KING, and MARY WHITTAKER

TECHNICAL BULLETINS (price $£ 1 \cdot 00 / \$ 2.00$ each)

22 Bilirubin standards and the determination of bilirubin by manual and technicon AutoAnalyzer methods January 1971 BARBARA BILLING, RUTH HASLAM, and N WALD

23 Interchangeable cells for spectrophotometers and fluorimeters September 1971 ss BROWN and AH GOWENLOCK

24 Simple tests to detect poisons March 1972 BW MEADE et al.

25 Blood gas analysers May 1972 K DIxON

26 Kits for enzyme activity determination September 1972 SB ROSALKI and D TARLOW

27 Assessment of pumps suitable for incorporation into existing continuous flow analytical systems November 1972 A FLECK et al.

28 Routine clinical measurements of transferrin in human serum September 1973 K DIXON
29 Control materials for clinical biochemistry (5th edition) September 1973 JF STEVENS

30 Notes on the quality of performance of serum cholesterol assays September 1973 SS BROWN

31 Determination of uric acid in blood and in urine July 1974 RWE WATTS

32 A survey of amino acid analysers readily available in the United Kingdom September 1974 JE CARLYLE and P PURKISS

33 Definitions of some words and terms used in automated analysis November 1974 A FLECK, R ROBINSON, SS BROWN, and JR HOBBS

34 Measurement of albumin in the sera of patients January 1975 LINDA SLATER, PM CARTER, and JR HOBBS

35 Investigation of the validity of temperature correction factors for serum aspartate and alanine transaminases March 1975 SB ROSALKI et al.

36 Factors influencing the assay of creatinine November 1975 JGH COOK

37 A survey of enzyme reaction rate analysers readily available in the United Kingdom July 1977 RA SAUNDERS and RF BURNS

38 Transport of specimens for clinical chemistry analysis November 1977 P WILDING, JF ZILVA, and CE WILDE

39 A scheme for the evaluation of diagnostic kits May 1978 PH LLOYD

40 A practical guide to gamma-counting in radioimmunoassay January 1980 CE WILDE and D OTTEWELL 